\title{
Traffic Control on Cruise Ships for Autonomous Vehicles Applying Artificial Neural Network
}

Ezequiel Gómez Dominguez

Department of Systems and Computation, Villahermosa Institute of Technology, México

Email: egomez@itvillahermosa.edu.mx

Jorge Cein Villanueva Guzman

Department of Systems and Computation, Villahermosa Institute of Technology, México

Email: jcvillanueva@itvillahermosa.edu.mx

Victor Manuel Arias Peregrino

Department of Systems and Computation, Villahermosa Institute of Technology, México

Email: varper@itvillahermosa.edu.mx

Julio Cesar Romellón Cerino

Department of Industrial Engineer, Villahermosa Institute of Technology, México

Email: julio.cerino@itvillahermosa.edu.mx

Juan Carlos Arias Peregrino

Department of Telecom, PEMEX, México

Email: ariasperegrino@gmail.com

The Artificial Neural Networks, from their origin, are oriented to solve problems in the same way as the human brain would. They use real data for their training and, through various algorithms, they seek to reach an optimal solution. In the present article the design of a Neuronal Artificial Network of multilayer perceptron type (PMC) for the control of autonomous vehicles in cruises is proposed. The training of the network was carried out applying Hyperbolic Tangent Sigmoid, Hyperbolic Log-Sigmoid and finally the linear functions.

Keywords -Neural Network, Robotics, Multilayer Perceptron, automation.

\section{INTRODUCTION}

\begin{abstract}
Artificial Neural Networks are models that try to reproduce the behavior of the human brain. Being a model as such, search through simplification, find out what are the relevant elements of the system. The proper choice of its characteristics and a convenient structure allows the construction of networks capable of performing specific tasks [1].

Neural Networks have been developed as generalizations of mathematical models of the knowledge of man, taking into account some considerations such as:

The processing of information is done in many elements called neurons; The signals are passed between neurons through feeder links; each connection link has an assigned weight; each neuron applies an activation function to the network inputs to determine the output signal [2].
\end{abstract}

Over the years, research has been carried out in the field of traffic prediction applying artificial intelligence [3], [4], applying various techniques and methods. These developments seek to contribute to the field of Intelligent Transportation Systems (ITS) by providing new technologies for the development of autonomous vehicle prototypes and prediction systems [5], [6]. Some developments, propose the use of cameras and wireless technologies for communication between vehicles [4].

The previous investigations gave us the basis for what is proposed in this article.
Currently, RNAs are considered an emerging technology capable of being used in different commercial and military applications; one of those applications is in the control of autonomous vehicles.

The first autonomous vehicle emerged in 1925, when Francis Houdina showed the world the first vehicle controlled by radio without a pilot inside it; the vehicle was capable of changing gears and honking the horn [7]. Companies such as Google, Toyota, BMW, among others, have invested in research for the development of their autonomous vehicles.

With the development of these autonomous vehicles, the need arises to design an algorithm capable of allowing two vehicles next to a cruise, determine who should cross first taking into account the one that is closest to that crossing. In this article, we propose the development of a multilayer artificial neural network to control the passage of autonomous vehicles on a cruise.

The simulation of the obtained network was carried out in two autonomous line following vehicles that use the Atmega328 processor with wireless communication using Xbee technology.

\section{METHODOLOGY}

To design the Artificial Neural Network, it was necessary to identify our input neurons, identify the activation function, and calculate the hidden layers necessary to obtain the desired results. 
Training an RNA is an essential process to reach the desired goal. Currently there are many platforms that allow this task from a personal computer, although this does not mean that with a single processor we can solve RNA with thousands of neurons. For the training of the network, the Matlab software was used, which provides many functions and tools that allow us to train and see the behavior of our RNA [8]. In addition, an Excel sheet was used to compare the data obtained by the Matlab software. Subsequently, the necessary code was developed in $\mathrm{C}++$ to be loaded in autonomous vehicles.

\subsection{TOPOLOGY}

In Figure 1, the topology of the Artificial Neural Network with all its inputs, hidden layers and outputs is shown. This topology uses 4 inputs, two hidden layers and one output.

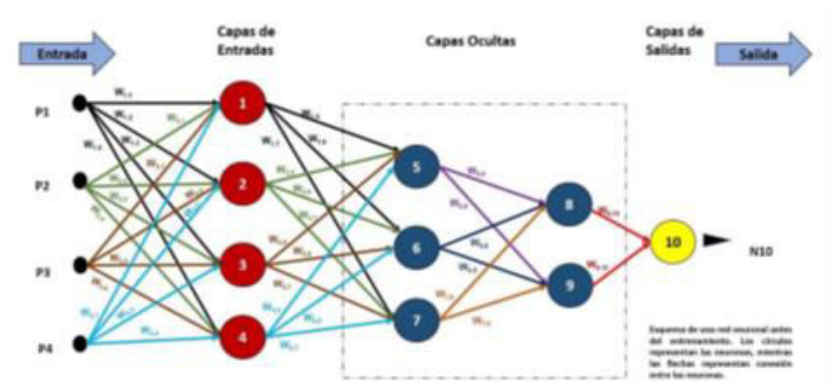

Fig 1. Topology of the artificial neural network.

\subsection{MATHEMATICAL MODEL FOR THE CALCULATION OF HIDDEN NETWORKS}

The hidden layers, obey the following formulas:

- First layer

$$
H_{1}=m * r^{2}
$$

- Second layer

$$
\begin{aligned}
& H_{2}=m * r \\
& r=\sqrt[3]{n / m}
\end{aligned}
$$

Where $\mathrm{H}_{1}$ and $\mathrm{H}_{2}$ is the number of neurons in the first and second layers respectively, $\mathrm{m}$ the number of output neurons, and $\mathrm{n}$ is the number of input neurons.

The following values apply to the previous model:

$$
\begin{aligned}
& n=4 \\
& m=1
\end{aligned}
$$

And the result obtained for $\mathrm{H}_{1}$ and $\mathrm{H}_{2}$ are as follows:

$$
\begin{gathered}
r=1.587 \\
H_{1}=2.51=3
\end{gathered}
$$

$$
H_{2}=1.58=2
$$

\subsection{EQUATIONS OF NEURAL NETWORKS}

The resulting RNA equations are the following:

- $\quad$ First layer of 4 neurons

$n_{1}=w_{11} p_{1}+w_{21} p_{2}+w_{31} p_{3}+w_{41} p_{4}+b_{1}$

$n_{2}=w_{12} p_{1}+w_{22} p_{2}+w_{32} p_{3}+w_{42} p_{4}+b_{2}$

$n_{3}=w_{13} p_{1}+w_{23} p_{2}+w_{33} p_{3}+w_{43} p_{4}+b_{3}$

$n_{1}=w_{14} p_{1}+w_{24} p_{2}+w_{34} p_{3}+w_{44} p_{4}+b_{4}$

- $\quad$ Second layer of 3 neurons

$n_{5}=w_{15} a_{1}+w_{25} a_{2}+w_{35} a_{3}+w_{45} a_{4}+b_{5}$

$n_{6}=w_{16} a_{1}+w_{26} a_{2}+w_{36} a_{3}+w_{46} a_{4}+b_{6}$

$n_{7}=w_{17} a_{1}+w_{27} a_{2}+w_{37} a_{3}+w_{47} a_{4}+b_{7}$

- $\quad$ Third layer of 3 neurons

$$
\begin{gathered}
n_{8}=w_{58} a_{5}+w_{68} a_{6}+w_{78} a_{7}+b_{8} \\
n_{9}=w_{59} a_{6}+w_{69} a_{6}+w_{79} a_{7}+b_{9}
\end{gathered}
$$

- $\quad$ Fourth layer of 1 neurons (output)

$$
n_{10}=w_{810} a_{8}+w_{910} a_{9}+b_{10}
$$

\subsubsection{ACTIVATION FUNCTION OF EACH} LAYER

- First layer of 4 neurons:

○ Function Hyperbolic Tangent Sigmoid.

$$
\begin{gathered}
f\left(n_{i}\right)=\frac{e^{n i}-e^{-n i}}{e^{n i}+e^{-n i}} \\
a_{i}=f\left(n_{i}\right) \\
a_{1}=\frac{e^{n 1}-e^{-n 1}}{e^{n 1}+e^{-n 1}} \\
a_{2}=\frac{e^{n 2}-e^{-n 2}}{e^{n 2}+e^{-n 2}} \\
a_{3}=\frac{e^{n 3}-e^{-n 3}}{e^{n 3}+e^{-n 3}} \\
a_{4}=\frac{e^{n 4}-e^{-n 4}}{e^{n 4}+e^{-n 4}}
\end{gathered}
$$

- Second layer of 3 neurons:

○ Function Hyperbolic Tangent Sigmoid.

$$
\begin{aligned}
& a_{5}=\frac{e^{n 5}-e^{-n 5}}{e^{n 5}+e^{-n 5}} \\
& a_{6}=\frac{e^{n 6}-e^{-n 6}}{e^{n 6}+e^{-n 6}}
\end{aligned}
$$




$$
a_{7}=\frac{e^{n 7}-e^{-n 7}}{e^{n 7}+e^{-n 7}}
$$

- Third layer of 2 neurons:

○ Function hyperbolic log-sigmoid.

$$
\begin{gathered}
f\left(n_{i}\right)=\frac{1}{1+e^{-n i}} \\
a_{i}=f\left(n_{i}\right) \\
a_{8}=\frac{1}{1+e^{-n 8}} \\
a_{9}=\frac{1}{1+e^{-n 9}}
\end{gathered}
$$

- Fourth layer of 1 neuron: Linear Function.

$$
\begin{gathered}
a_{i}=n_{i} \\
a_{10}=f\left(n_{10}\right)
\end{gathered}
$$

\section{RESUltS}

After obtaining the RNA for the cruise control of two autonomous vehicles [9], we proceeded to the assembly, configuration and coding of the RNA in Arduino platform.

\subsection{ASSEMBLY OF AUTONOMOUS VEHICLES}

For the design of the vehicles, the car chassis kit with idler wheel was used, which has two gearmotors with wheels and it was necessary to install an H L298N bridge, an ultrasonic sensor was also installed that allows us to identify nearby elements and to avoid in a given case, a collision, and finally, an infrared sensor module TCRT5000 of 3 sensors was installed, which we used to follow the black line [10] and later, identify the cruise, finally, uses the Xbee version 2, to establish communication between both vehicles and identify who will pass first and who will do it later.

The Figure 2, shown the connection diagram of electronic elements for build the autonomous vehicle.

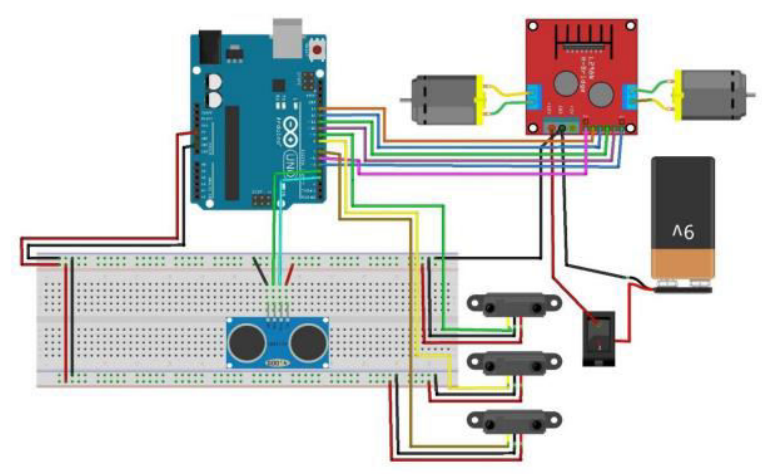

Fig 2. Connection diagram of the autonomous vehicle.

In Figures 3 and 4, evidence of the assembly and configuration of the two autonomous vehicles is presented.
Finally in Figure 5, the final design of the two assembled vehicles is shown.

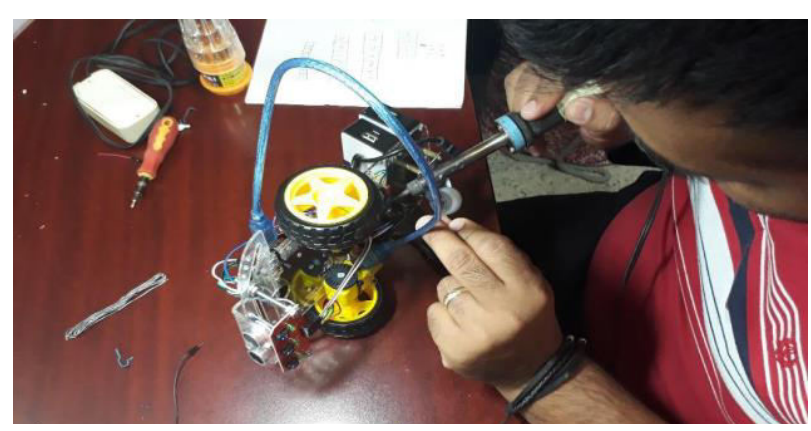

Fig 3. Connection of gearmotors.

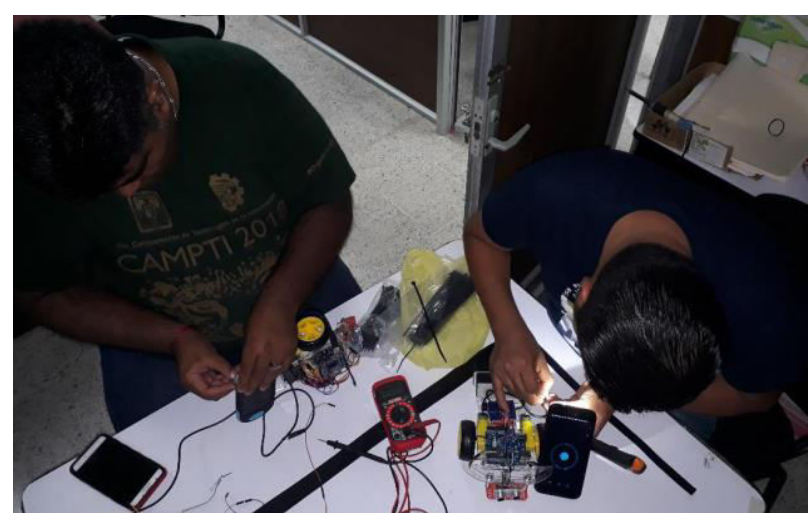

Fig 4. Assembly of electronic cards and sensors

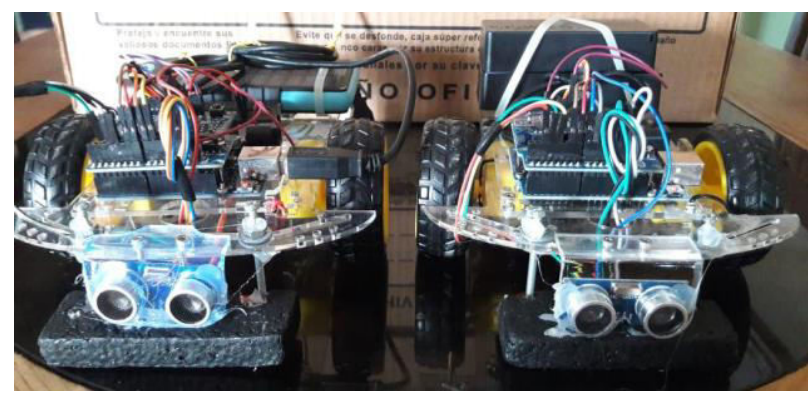

Figure 5. Final design of the two vehicles.

\subsection{TRACK DESIGN}

To do perform the performance tests, it was necessary to design a way track on which to put the vehicles and wait to act according of the RNA.

In Figure 6, the two tracks used to configure and check the operation of autonomous vehicles are shown.

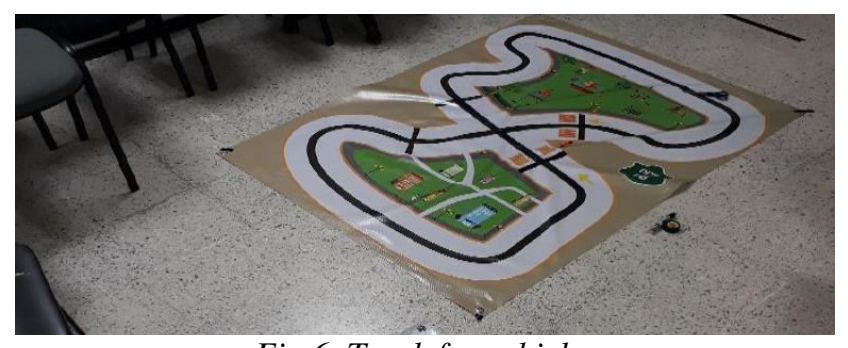

Fig 6. Track for vehicles 


\subsection{SOURCE CODE}

Next, the function of the RNA in $\mathrm{C}++$ loaded to both vehicles is presented through the use of electronic cards based on the Atmega328 processor.

void crucero() \{

//activamos la badera de crucero bandera $=1$; cruceroL $=1$;

//Serial.println(String("ultra: ")+ String(distancia));

if(distancia $>10)$

distanciaL $=1$;

else

distanciaL $=0$;

//usamos la red neuronal $\operatorname{red}()$;

\}

void red()

\{
/*Valores de entrada de la red*/

p1=distanciaL;

p2=cruceroL;

p3=distanciaR;

$\mathrm{p} 4=$ cruceroR;

/*Primer capa de 4 neuronas*/

$\mathrm{n} 1=\mathrm{p} 1 *(0.8888)+\mathrm{p} 2 *(2.7953)+\mathrm{p} 3 *(-2.4129)$

$+\mathrm{p} 4 *(1.0267)+(-3.1828)$;

$\mathrm{n} 2=\mathrm{p} 1 *(1.3371)+\mathrm{p} 2 *(-2.6368)+\mathrm{p} 3 *(0.971)$

$+\mathrm{p} 4 *(2.4475)+(-1.7216)$;

$\mathrm{n} 3=\mathrm{p} 1 *(2.2331)+\mathrm{p} 2 *(2.6106)+\mathrm{p} 3 *(-0.622)$

$+\mathrm{p} 4 *(-1.8684)+(-0.5167)$;

$\mathrm{n} 4=\mathrm{p} 1 *(1.6044)+\mathrm{p} 2 *(-3.0417)+\mathrm{p} 3 *(0.48)$

$+\mathrm{p} 4 *(1.8839)+(2.0475)$;

/* Analisis Tansig */

$\mathrm{s} 1=\tan \operatorname{sig}(\mathrm{n} 1)$;

$\mathrm{s} 2=\tan \operatorname{sig}(\mathrm{n} 2)$;

$\mathrm{s} 3=\tan \operatorname{sig}(\mathrm{n} 3)$;

s4=tansig(n4);

/*Segunda capa de 3 neuronas*/

$\mathrm{n} 5=\mathrm{s} 1 *(-0.4919)+\mathrm{s} 2 *(-$

$1.4052)+\mathrm{s} 3 *(0.2296)+\mathrm{s} 4 *(-1.049)+(1.8473)$; $\mathrm{n} 6=\mathrm{s} 1 *(0.9643)+\mathrm{s} 2 *(0.36)+\mathrm{s} 3 *(1.028)+\mathrm{s} 4 *(-$

$1.1105)+(-0.0342)$;

$\mathrm{n} 7=\mathrm{s} 1 *(1.0116)+\mathrm{s} 2 *(0.2538)+\mathrm{s} 3 *(-$

$0.7195)+\mathrm{s} 4 *(1.3372)+(1.8391)$;

/* Analisis Tansig */

s5=tansig(n5);

$\mathrm{s} 6=\tan \operatorname{sig}(\mathrm{n} 6)$;

$\mathrm{s} 7=\tan \operatorname{sig}(\mathrm{n} 7)$;

/*Tercera capa de 2 neuronas */

$\mathrm{n} 8=\mathrm{s} 5 *(2.0321)+\mathrm{s} 6 *(1.9518)+\mathrm{s} 7 *(2.0613)+(-$ 3.5494);

$\mathrm{n} 9=\mathrm{s} 5 *(-1.1006)+\mathrm{s} 6 *(2.3914)+\mathrm{s} 7 *(2.3464)+(-$

3.5295);

/* Analisis Logsig */

$\mathrm{s} 8=\log \operatorname{sig}(\mathrm{n} 8)$;

$\mathrm{s} 9=\log \operatorname{sig}(\mathrm{n} 9)$;

/*Cuarta capa de 1 neurona */

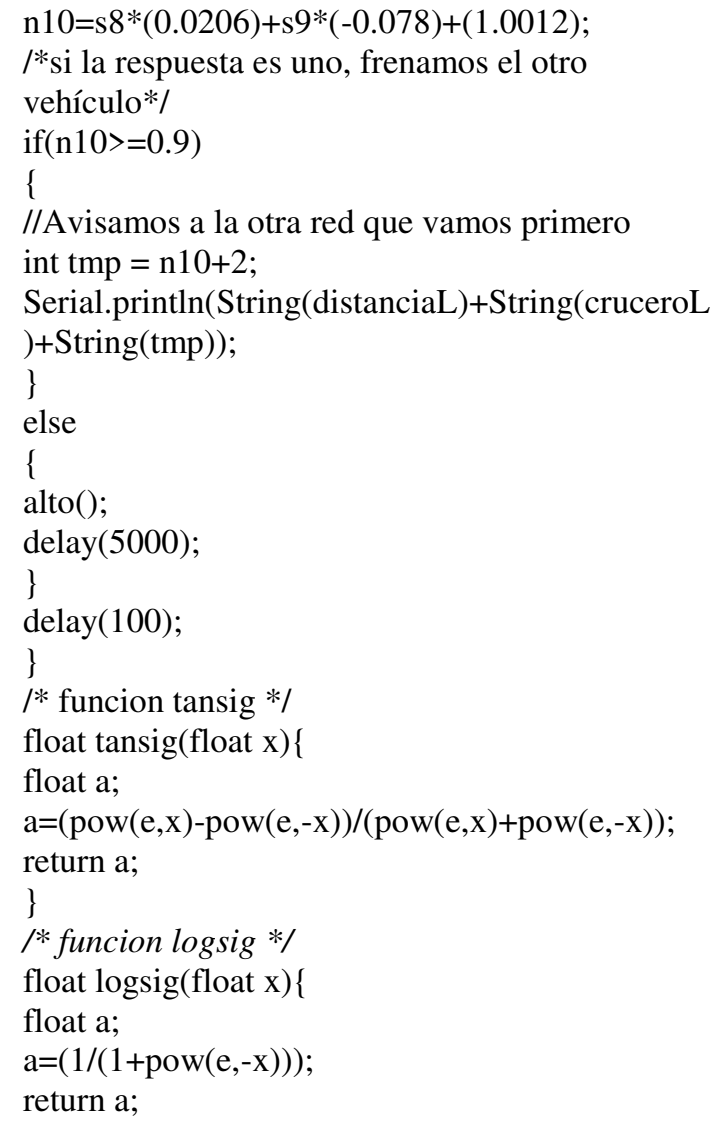

\section{CONCLUSION}

We interpret artificial intelligence as the application of cognitive or thought functions performed by a machine or equipment, for the solution of problems, maximizing with this their probabilities of success, granting us a proposal of satisfactory solution to our needs [11].

The RNA designed in the project is defined as a computational system that is composed of a considerable amount of simple elements, elements of properly interconnected processes, which have the obligation to process the information by means of their dynamic state in response to the initial inputs. Which are the sensors used in each of the vehicles involved to cross the road, without any road accident taking place.

The experience lived in this project was to find a neural network capable of deciding which car passes first at the road junction, with the information generated by Xbee communication, with the support of two sensors (Ultrasonic HC-SR04 and infrared TCRT5000), working the Neural network through the start layer, two hidden layers and the output layer.

\section{Discussion}

The investigations of the neural networks in the road field, are still scarce, but the existing ones, allow to identify the importance of these to solve traffic problems, mainly that of reducing the number of road accidents. 
In addition, we found that there are already some vehicles with different sensors that, using RNA and I.A., are autonomous and the ability to react to a collision is much greater than that of the human being.

\section{REFERENCES}

[1] J. R. Hilera Gonzalez, Redes neuronales artificiales: fundamentos, modelos y aplicaciones. Mexico, 2000.

[2] H. Delgado, A. Pedro, G. Arestuche, y L. Roberto, "Análisis neuronal de variables fusificadas para la caracterización y determinación del rating de un puente de carretera", 2010.

[3] L. F. . Torres Alvarez, Nelson; Hernandez, Cesar; Pedraza, "Neural networks and prediction of traffic", Tecnura, vol. V, núm. 29, pp. 90-97, 2011.

[4] V. Milanés, E. Onieva, J. Pérez, y T. D. P. C. González, "Control de Velocidad basado en Lógica Borrosa para Entornos Urbanos Congestionados", Revista Iberoamericana de Automática e Informática Industrial RIAI, vol. 6, núm. 4, pp. 61-68, 2009.

[5] A. Felipe y A. Gil, "Sistema de Toma de Decisiones Basado en Modelo para Cambios de Carril en Vehiculos Autonomos", 2016.

[6] A. Gomez Torres, "Control de crucero cooperativo mediante comunicaciones V2X", Universidad Politécnica de Madrid, 2018.

[7] T. M. Sentinel, "Phantom Auto' will tour city", The Milwaukee Sentinel, Ney York, p. 14, 08-dic1926.

[8] O. Cervantes y D. Báez, Matlab con Aplicaciones a la Ingeniería, Física y Finanzas, 2a ed. México: Alfaomega, 2012.

[9] J. E. Universitat Autònoma de Barcelona. Grupo de Investigación "Didáctica y Multimedia.” y J. H. Ruiz F., Didáctica, innovación y multimedia., núm. 30. Universidad Autònoma de Barcelona, Facultad de Educación, Departamento de Pedagogía Aplicada, 2014.

[10] J. Reyna, "Diseño y construcción de un microbot seguidor de linea controlado por un microcontrolador PIC16F84", Mendoza, 2009.

[11] P. Ponce, Inteligencia Artificial con Aplicaciones a la Ingeniería, 1a ed. Alfaomega, 2010.

\section{Biographies and Photographs}
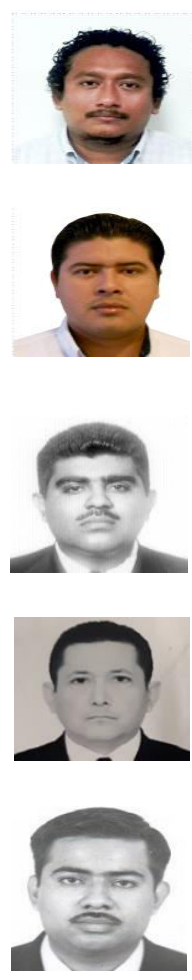

Ezequiel Gomez Dominguez.Master in Computer Technologies. He is currently a $\mathrm{PhD}$ student. His research area is the development of new technologies.

Jorge Cein Villanueva Guzman. Master in Information Technology. He is currently a $\mathrm{PhD}$ student. His research area is the development of embedded systems.

Victor Manuel Arias Peregrino. Master in Computer Technologies. He is currently a $\mathrm{PhD}$ student. His research area is the development of new technologies.

Julio Cesar Romellon Cerino. Master $\mathrm{He}$ is currently a $\mathrm{PhD}$ student. His research area is the development of new technologies.

Juan Carlos Arias Peregrino.Master in Computer Technologies. He is currently a $\mathrm{PhD}$ student. His research area is the development of new technologies. 